$\mathrm{K}$

STUDIA Z PRAWA WYZNANIOWEGO

Tom $22-2019$

DOI: https://doi.org/10.31743/spw.5281

\title{
DUSZPASTERSTWO W SYSTEMIE PENITENCJARNYM FEDERACJI ROSYJSKIEJ
}

\section{Streszczenie}

Zasadniczym celem niniejszego artykułu jest przedstawienie konstytucyjnych, ustawowych oraz podustawowych uwarunkowań normatywnych funkcjonowania duszpasterstwa więziennego w Federacji Rosyjskiej. Przedmiotem opracowania jest także przybliżenie praktyki funkcjonowania odradzającego się w Rosji duszpasterstwa więziennego wraz $\mathrm{z}$ występującymi problemami oraz rosnącej roli związków wyznaniowych w tym zakresie. Jednocześnie na tym tle dokonano ogólnej charakterystyki rosyjskiego systemu penitencjarnego, wskazując na jego kluczowe elementy, w tym centralny organ zarządzający - Federalną Służbę Wykonywania Wyroków Rosji. Celem artykułu jest również wskazanie niedoskonałości obowiązujących przepisów prawnych i praktyki organów państwowych związanych z funkcjonowaniem duszpasterstwa więziennego w Federacji Rosyjskiej. W konkluzji rozważań przedstawiono perspektywę dalszej ewolucji pozycji prawnej duszpasterstwa więziennego w Rosji. Rezultatem przeprowadzonych badań jest zasadniczy wniosek o potrzebie reformy rosyjskiego systemu funkcjonowania duszpasterstwa więziennego w celu skutecznego zagwarantowania wolności sumienia i wyznania osobom pozbawionym wolności.

Słowa kluczowe: Federacja Rosyjska; wolność sumienia i wyznania; Federalna Służba Wykonywania Wyroków Rosji; system penitencjarny; duszpasterstwo więzienne; kapelan

$$
* * * * *
$$

* Dr hab. Jarosław Matwiejuk, adiunkt, Katedra Prawa Konstytucyjnego i Systemów Politycznych, Wydział Prawa, Uniwersytet w Białymstoku, ul. Świerkowa 20 B, 15-328 Białystok, e-mail: matwiejuk@uwb.edu.pl, ORCID 0000-0001-6346-330X. 


\section{WPROWADZENIE}

System penitencjarny Federacji Rosyjskiej jest jednym z największych istniejących systemów penitencjarnych we współczesnym świecie. Według danych World Prison Brief, Institute for Criminal Policy Research na dzień 1 września 2019 r. w Federacji Rosyjskiej pozbawionych wolności było 435713 osób ${ }^{1}$. W śród nich 18,4\% stanowili zatrzymani i tymczasowo aresztowani, $8 \%$ kobiety, $4,3 \%$ cudzoziemcy i $0,2 \%$ osoby niepełnoletnie. Rosyjski system penitencjarny składa się z 947 jednostek penitencjarnych, w tym: 210 aresztów śledczych, 702 kolonii karnych, 23 kolonii edukacyjnych dla osób niepełnoletnich, 8 więzień. Jednostki organizacyjne systemu penitencjarnego Rosji mogą maksymalnie przyjąć 812804 osoby $^{2}$. Rosja zaliczana jest do grupy państw o największej liczbie osób pozbawionych wolności (375 osób na 100 tyś. mieszkańców) ${ }^{3}$.

Duża liczba osób przebywających w różnego rodzaju miejscach odosobnienia była jedną z cech charakterystycznych państwa rosyjskiego zarówno w okresie Imperium Rosyjskiego ${ }^{4}$, jak i w okresie Związku Socjalistycznych Republik Radzieckich. Warto przypomnieć, że w okresie istnienia Głównego Zarządu Poprawczych Obozów Pracy ${ }^{5}$ w Związku Radzieckim przetrzymywano w różnego rodzaju obozach i łagrach rocznie do 2,5 mln osób ${ }^{6}$. Skazani byli wówczas pozbawieni wolności sumienia i wyznania oraz opieki duszpasterskiej w związku z konsekwentnie realizowaną marksistowsko-leninowską koncepcją socjalistycznego państwa świeckiego uznającego religię za relikt i jednocześnie wojującego z religią oraz związkami wyznaniowymi wszelkimi dostępnymi metodami ${ }^{7}$.

1 World Prison Brief, Institute for Criminal Policy Research, https://prisonstudies. org/country/russian-federation [dostęp: 27.09.2019] oraz http://fsin.su/structure/inspector/ iao/statistika/Kratkaya\%20har-ka\%20UIS/ [dostęp: 12.10.2019].

2 Tamże.

3 Dla porównania w Polsce wskaźnik ten wynosi 196 osób 100 tyś. mieszkańców. World Prison Brief, Institute for Criminal Policy Research, https://prisonstudies.org/country/ poland [dostęp: 27.08.2019].

4 Szerzej: Michalski 2018, 10-13.

5 GUŁAG - Gławnoje uprawlenije isprawitielno-trudowych łagieriej i kolonij.

6 Zemskov 1991, 10; Conquist 1997.

7 Matwiejuk 2016, 51-99. 
W Federacji Rosyjskiej nie ma legalnej definicji duszpasterstwa więziennego. Na potrzeby niniejszego opracowania przez duszpasterstwo więzienne będziemy rozumieć specjalne duszpasterstwo realizowane w stosunku do osób pozbawionych wolności i przebywających w różnego rodzaju jednostkach penitencjarnych ${ }^{8}$. Każdy ma wolność sumienia i wyznania. Wynika to z przyrodzonej godności człowieka. Jest to wolność niezbywalna i dlatego też wszystkim osobom pozbawionym wolności, w tym osobom skazanym na najsurowsze kary, przysługuje wolność sumienia i wyznania w pełnym zakresie, uwzględniającym oczywiście specyfikę miejsca przebywania. Obowiązkiem państwa oraz obowiązkiem personelu służb penitencjarnych jest zapewnienie realizacji uprawnień wynikających z wolności sumienia i wyznania określonych i zagwarantowanych przepisami prawa.

We współczesnym państwie zapewnienie opieki duszpasterskiej osobom pozbawionym wolności i przebywającym w jednostkach penitencjarnych zagwarantowane jest w aktach normatywnych rangi konstytucyjnej i ustawowej oraz podustawowej o charakterze wykonawczym. Podobnie jest w systemie prawnym Federacji Rosyjskiej. Zasady sprawowania przez związki wyznaniowe posługi duszpasterskiej i opieki religijnej nad osobami pozbawionymi wolności i przebywającymi w jednostkach penitencjarnych regulują różne akty normatywne. Rosyjska specyfika unormowania tej materii sprowadza się do konieczności dodatkowego uwzględnienia porozumień ramowych i porozumień terytorialnych zawieranych ze związkami wyznaniowymi przez odpowiednio: kierownictwo Federalnej Służby Wykonywania Wyroków Rosji (dalej: FSWWR) ${ }^{9}$ lub zarządy regionalne FSWWR. Porozumienia mają charakter typowych umów, w których następuje konkretyzacja regulacji ustawowej i doprecyzowanie zasad funkcjonowania duszpasterstwa w systemie penitencjarnym Rosji.

W związku z niedostatkiem aktualnych opracowań w literaturze przedmiotu należy postawić zasadnicze pytanie: jak wygląda współczesna nor-

8 Inną definicję duszpasterstwa więziennego zob. Krukowski 2008, 184. Autorowi nie jest znana rosyjska doktrynalna definicja duszpasterstwa więziennego.

9 Utworzony w 2004 r. organ federalny, który sprawuje kontrolę i nadzór nad wykonywaniem sankcji karnych. Nadzorowany jest przez Ministra Sprawiedliwości Federacji Rosyjskiej. 
matywna regulacja duszpasterstwa w systemie penitencjarnym Federacji Rosyjskiej? Oczywiście, to ogólne zagadnienie badawcze należy uszczegółowić, stawiając następujące konkretne pytania badawcze: jakie są niedostatki normatywnej regulacji duszpasterstwa w systemie penitencjarnym Federacji Rosyjskiej oraz w jakim kierunku możliwa jest dalsza ewolucja pozycji prawnej duszpasterstwa więziennego w Rosji?

KONSTYTUCYJNE PODSTAWY DUSZPASTERSTWA

W SYSTEMIE PENITENCJARNYM FEDERACJI ROSYJSKIEJ

Podstawę prawną funkcjonowania duszpasterstwa więziennego we współczesnej Rosji stanowi Konstytucja Federacji Rosyjskiej z dnia 12 grudnia $1993 \mathrm{r}^{10} \mathrm{~W}$ ustawie zasadniczej nie ma mowy wprost o opiece duszpasterskiej w systemie penitencjarnym. Brak jest zapisu o prawie jednostki do korzystania z pomocy religijnej tam, gdzie się znajduje ${ }^{11}$. Jednak doktryna rosyjska oraz związki wyznaniowe powszechnie uznają za podstawę do funkcjonowania duszpasterstwa więziennego art. 28 Konstytucji Federacji Rosyjskiej, który stanowi, że każdemu gwarantuje się wolność sumienia i wolność wyznania, łącznie z prawem do indywidualnego lub wspólnie $\mathrm{z}$ innymi wyznawania dowolnej religii lub niewyznawania żadnej, do swobodnego wyboru, posiadania i rozpowszechniania przekonań religijnych i innych oraz postępowania $\mathrm{w}$ zgodzie z nimi. Za kluczowe dla duszpasterstwa więziennego uznaje się dwa uprawnienia zawarte w konstytucyjnym ujęciu wolności sumienia i wyznania: prawo do indywidualnego wyznawania dowolnej religii oraz prawo każdego do postępowania w zgodzie z przekonaniami religijnymi. Realizacja uprawnień tworzących wolność sumienia i wyznania nie jest powiązana z koniecznością członkostwa w związkach wyznaniowych ${ }^{12}$.

10 Konstytucja Federacji Rosyjskiej przyjęta w ogólnonarodowym referendum w dniu 12 grudnia 1993 r. ,Rossijskaja Gazeta” 1993, nr 237; http://constitution.kremlin.ru/. Thum. Andrzej Kubik. 2000. Warszawa: Wydawnictwo Sejmowe.

11 W przeciwieństwie do Konstytucji Rzeczypospolitej Polskiej z dnia 2 kwietnia 1997 r. (Dz. U. z 1997 r. Nr 78, poz. 483 z późn. zm.), która w art. 53 ust. 2 stanowi o prawie osób do korzystania z pomocy religijnej tam, gdzie się znajdują.

12 Iwanow 2002, 187. 
W literaturze rosyjskiej mocno akcentuje się niedopuszczalność zmuszania jednostki do wyboru i zmiany wyznawanej religii ${ }^{13}$, co w realiach państwa postkomunistycznego ma szczególne znaczenie ${ }^{14}$.

Wolność sumienia i wyznania przysługuje każdej osobie fizycznej i nie ma znaczenia posiadanie lub nie obywatelstwa, płeć, rasa, narodowość, wiek, język, pochodzenie, stan majątkowy, wykształcenie, służba lub stanowisko w aparacie publicznym, miejsce zamieszkania, stan zdrowia, wyznawana religia, przekonania, członkowstwo w organizacjach społecznych, a także inne okoliczności np. zatrzymanie, tymczasowe aresztowanie czy prawomocne skazanie za przestępstwo. W związku z powyższym opieka duszpasterska w systemie penitencjarnym kierowana jest nie tylko do osób pozbawionych wolności, ale również do całego personelu pełniącego służbę i zatrudnionego w jednostkach penitencjarnych wszystkich typów.

Wolność sumienia i wyznania adresowana jest oprócz osób fizycznych również do innych podmiotów w tym przede wszystkim związków wyznaniowych oraz innych organizacji społecznych działających legalnie na terenie Rosji. Po wejściu w życie konstytucji związki wyznaniowe korzystając z art. 28 Konstytucji Federacji Rosyjskiej, a w szczególności zagwarantowanemu każdemu uprawnieniu do postępowania $\mathrm{w}$ zgodzie $\mathrm{z}$ przekonaniami religijnymi, wyinterpretowały prawo do opieki duszpasterskiej m.in. w systemie penitencjarnym, a następnie zaczęły spontanicznie i dynamicznie organizować opiekę duszpasterską w jednostkach rosyjskiego systemu penitencjarnego.

Jednym z celów Konstytucji Federacji Rosyjskiej jest trwałe zerwanie z radzieckimi rozwiązaniami normatywnymi i stworzenie - wzorem państw demokratycznych - nowej formuły prawnej dla poszerzenia działalności związków wyznaniowych w celu wykorzystania ich potencjału m.in. do resocjalizacji osób pozbawionych wolności oraz ograniczenia przestępczości. Celami są także: zagwarantowanie każdemu wolności sumienia i wyznania oraz reaktywacja duszpasterstwa specjalnego, w tym duszpasterstwa więziennego.

13 Barchatowa 2018, 47.

14 Bagłaj 2002, 202. 
Konkretyzacja zakresu działalności i uprawnień odradzającego się duszpasterstwa więziennego nastąpiła w aktach normatywnych rangi ustawowej uchwalonych w latach 90. XX oraz na początku XXI wieku.

\section{USTAWOWE PODSTAWY DUSZPASTERSTWA W SYSTEMIE PENITENCJARNYM FEDERACJI ROSYJSKIEJ}

W literaturze rosyjskiej podkreślane jest fundamentalne znaczenie ustawy federalnej z 26 września 1997 r. o wolności sumienia i o związkach wyznaniowych ${ }^{15}$, która po raz pierwszy po rozpadzie Związku Radzieckiego dopuściła możliwość i określiła ramy współpracy między związkami wyznaniowymi i jednostkami penitencjarnymi ${ }^{16}$. Ustawodawca federalny w art. 16 ust. 3 przyznał związkom wyznaniowym prawo do przeprowadzania obrzędów religijnych i organizowania ceremonii religijnych we wszystkich jednostkach penitencjarnych, w których przebywają osoby pozbawione wolności. Obrzędy religijne i ceremonie religijne sprawowane są na wniosek (w dosłownym tłumaczeniu „na prośbę”) przebywających w tych jednostkach obywateli. Ustawodawca federalny jednocześnie wskazuje, że muszą one być sprawowane w zgodzie z wymogami Kodeksu postępowania karnego Federacji Rosyjskiej z 18 grudnia 2011 r. ${ }^{17}$, a wszelkie naruszenia lub ograniczenia tego prawa stanowią przestępstwo i są ścigane oraz karane na podstawie art. 136 Kodeksu karnego Federacji Rosyjskiej z 13 czerwca 1996 r. $^{18}$

Należy podkreślić, że w świetle ustawy federalnej z 26 września 1997 r. o wolności sumienia i o związkach wyznaniowych adresatem uprawnienia do uczestniczenia $\mathrm{w}$ obrzędach i ceremoniach religijnych jest obywatel Rosji. Jest to sprzeczne $\mathrm{z}$ konstytucyjnym ujęciem adresata wolności sumienia i wyznania, którym jest każdy, a nie tylko obywatel. Mamy zatem

15 Federalnyj zakon ot 26 sientiabria 1997 g. o swobodie sowiesti i o religoznych objedinienijach, Sobranie Zakonodatielstwa Rossijskoj Federacji 1997, nr 39, st. 4465.

16 Żezłow 2016, 61.

17 Ugołowno-processualnyj kodeks RF ot 18 diekabria 2001 g, Sobranie Zakonodatielstwa Rossijskoj Federacji 2001, nr 52, st. 4921.

18 Ugołownyj kodeks RF ot 13 ijunia 1996 g., Sobranie Zakonodatielstwa Rossijskoj Federacji 1996, nr 25, st. 2954. 
do czynienia z ustawowym zawężeniem kręgu adresatów wolności sumienia i wyznania. Podnoszony jest postulat usunięcia tej niespójności w drodze nowelizacji ustawy federalnej o wolności sumienia i o związkach wyznaniowych.

Na podstawie ustawy federalnej z 26 września 1997 r. o wolności sumienia i o związkach wyznaniowych zagwarantowano tajemnicę spowiedzi z jednoczesnym wyłączeniem możliwości przesłuchiwania jako świadków duchownych co do faktów, o których dowiedzieli się w trakcie spowiedzi ${ }^{19}$.

Pełna praktyczna legalizacja działalności duszpasterstwa więziennego została dokonana na podstawie Kodeksu karnego wykonawczego Federacji Rosyjskiej z 8 stycznia 1997 r. ${ }^{20}$, który w art. 8 zawiera m.in. zasadę humanizmu i równości skazanych wobec prawa ${ }^{21}$. Proces jego legalizacji nastąpił po długich dyskusjach i przygotowaniach ${ }^{22}$. Ustawodawca w art. 14 Kodeksu karnego wykonawczego Federacji Rosyjskiej zagwarantował wolność sumienia i wyznania osobom pozbawionym wolności. Jest ona rozumiana jako zbiór uprawnień do: swobodnego wyboru, posiadania oraz zmiany wyznawanej religii lub niewyznawania żadnej. Wolność ta jest „dobrowolna” i jej realizacja nie może w jakikolwiek sposób naruszać przepisów wewnętrznych zakładów karnych oraz praw innych osób tam przebywających. Przepis ten wywołuje w rosyjskiej doktrynie prawnej poważne wątpliwości interpretacyjne. Stawiane jest zasadnicze pytanie, co jest ważniejsze: realizacja ustawowo zagwarantowanej wolności sumienia i wyznania czy przepisy wewnętrzne jednostek penitencjarnych? Nie ulega najmniejszej wątpliwości, że przy takiej redakcji przepisu uprawnienia wynikające $\mathrm{z}$ wolności sumienia $\mathrm{i}$ wyznania mogą być zagrożone $\mathrm{w}$ praktyce funkcjonowania jednostek organizacyjnych rosyjskiego systemu penitencjarnego.

19 Art. 3 ust.7 ustawy federalnej z 26 września 1997 r. o wolności sumienia i o związkach wyznaniowych.

20 Ugołowno-ispołnitielnyj kodeks RF ot 8 janwaria 1997 g., „Rossijskaja Gazeta” 1997, nr 9.

21 Więcej na temat zasad funkcjonowania systemu penitencjarnego w Rosji zob. Malinin 2010 oraz Dietkow 1999.

22 Bajdakov 1995, 91. 
Osoby, które są pozbawione wolności mają prawo do składania prośby skierowanej do kierownictwa jednostki penitencjarnej o osobiste spotkanie $\mathrm{z}$ osobą duchowną reprezentującą wybrany przez zainteresowanego zarejestrowany związek wyznaniowy ${ }^{23}$. Zasadnicze znaczenie ma zatem właściwe rozumienie istoty wolności sumienia i wyznania jako wolności nie tylko ustawowej, ale przede wszystkim konstytucyjnej wolności osobistej jednostki, a także odpowiedzialność kadry kierowniczej decydującej o tej wolności w praktyce ${ }^{24}$. Liczba spotkań osoby pozbawionej wolności z osobą duchowną nie jest ustawowo ograniczona. Ustawodawca wskazuje jednak, że indywidualne spotkanie nie może trwać dłużej niż dwie godziny i odbywa się zawsze $\mathrm{w}$ obecności pracownika FSWWR ${ }^{25}$. Jest to zaskakujące rozwiązanie i może budzić pewne wątpliwości. Jednocześnie warto zauważyć, że przepisy dopuszczają, aby osoby pozbawione wolności mogły wnioskować do kierownictwa jednostki penitencjarnej o osobiste spotkanie bez udziału pracownika FSWWR. Jest to możliwe w celu przeprowadzenia jedynie obrzędów religijnych i rytuałów. Spotkanie osobiste osoby pozbawionej wolności z osobą duchowną bez udziału pracownika FSWWR wymaga uzyskania każdorazowo pisemnej zgody osoby duchownej reprezentującej zarejestrowany związek wyznaniowy. Spotkanie takie jest zawsze utrwalane przy pomocy kamer systemu monitoringu wizyjnego.

Osoby pozbawione wolności na podstawie art. 14 ust. 4 Kodeksu karnego wykonawczego Federacji Rosyjskiej mają także uprawnienie do posiadania przedmiotów niezbędnych dla sprawowania kultu i prawo do posiadania literatury religijnej. Prawa te nie zostały w żaden sposób uszczegółowione. W ustawie nie nastąpiło sprecyzowanie pojęcia przedmiotów potrzebnych do kultu religijnego. W praktyce funkcjonowania jednostek systemu penitencjarnego Rosji dopuszczalne jest posiadanie i korzystanie z przedmiotów niezbędnych dla sprawowania kultu o niewielkich rozmiarach. Jednocześnie warto zauważyć, że dostępność do

${ }^{23}$ Art. 14 ust. 4 Kodeksu Karnego Wykonawczego Federacji Rosyjskiej z 8 stycznia $1997 \mathrm{r}$.

24 Smirnow 2013, 2-5.

25 Federalna Służba Wykonywania Wyroków Rosji w latach 2004-2019 nie była wolna od afer korupcyjnych, nadużyć i skandali szeroko przedstawianych opinii publicznej przez środki masowego przekazu. 
przedmiotów potrzebnych do kultu religijnego jest ograniczana w przypadku, gdy ich kształt, budowa lub ciężar mogą zagrażać życiu i zdrowiu osadzonych. Prawo do posiadania literatury religijnej obejmuje szeroko rozumianą literaturę o treści religijnej, w tym oczywiście najważniejsze dzieła o fundamentalnym znaczeniu dla konkretnych wyznawców, oraz pozycje o charakterze katechetyczno-kształceniowym. Literatura religijna rozumiana jest jako tradycyjne książki, czasopisma oraz inne pozycje zapisane także w formie elektronicznej. Osoby pozbawione wolności mają prawo do przeprowadzania i uczestniczenia w obrzędach religijnych i rytuałach w świątyniach lub specjalnie przygotowanych pomieszczeniach znajdujących się na terenie jednostki penitencjarnej.

Warto podkreślić, że skazani będący w ciężkich stanach chorobowych oraz osoby skazane na karę śmierci mają zagwarantowaną możliwość realizacji wszystkich obrzędów i czynności religijnych zgodnych z wyznawaną przez nich religią. Osoby takie mają prawo do spotkania z kapelanem więziennym swojego wyznania ${ }^{26}$.

Przyznanie osobom skazanym prawa do wolności sumienia i wyznania opiera się zatem na podstawowych czterech zasadach: 1) legalności - prawa te muszą być realizowane przez skazanych w ścisłej zgodzie z prawem i innymi regulaminami, 2) pierwszeństwa przestrzegania przepisów wewnętrznych systemu więziennictwa nad wdrażaniem przez skazanych prawa do wolności sumienia i wyznania, 3) dobrowolności - prawo jest wykonywane przez skazanych z własnej woli, bez przymusu lub przemocy oraz 4) dostępności - zapewnienie skazanym wszelkich dostępnych okazji do wykonywania obrzędów religijnych, spotkań z wiernymi i zapoznawania się z literaturą religijną ${ }^{27}$.

Bardzo ważnym aktem normatywnym dla określenia pozycji prawnej duszpasterstwa więziennego w Rosji jest ustawa federalna z dnia 15 lipca 1995 r. o zatrzymaniu podejrzanych i oskarżonych o popełnienie przestępstwa ${ }^{28}$. Ustawa określa uprawnienia osób podejrzanych i oskarżonych

26 Art. 14 ust. 6 Kodeksu karnego wykonawczego Federacji Rosyjskiej z 8 stycznia $1997 \mathrm{r}$.

27 Vshivkova 2015, 475-478.

28 Federalnyj zakon ot 15 ijulia 1996 g. O sodierżanii pod strażej podozriewajemych i obwiniajemych w sowierszenii prestuplenij, Sobranie Zakonodatielstwa Rossijskoj Federacji 1996, nr 29, st. 2759. 
osadzonych w jednostkach rosyjskiego systemu penitencjarnego, w tym w szczególności w tzw. „izolatorach śledczych”, które są odpowiednikiem polskich aresztów śledczych. Na podstawie art. 17 pkt. 14 ustawy federalnej osoby oskarżone i podejrzane o popełnienie przestępstwa mają trzy zasadnicze uprawnienia związane integralnie z wolnością sumienia i wyznania. Zaliczyć do nich należy przede wszystkim prawo do odprawiania obrzędów religijnych w pomieszczeniach miejsca zatrzymania, w tym w szczególności w celach i izolatkach. Naturalnie prawo to obejmuje także uczestniczenie w obrzędach religijnych sprawowanych przez osoby duchowne w świątyniach i kaplicach oraz innych pomieszczeniach znajdujących się w jednostkach systemu penitencjarnego.

Ponadto osoby oskarżone i podejrzane o popełnienie przestępstwa na podstawie art. 17 pkt. 14 ustawy federalnej mają prawo do posiadania literatury religijnej i przedmiotów potrzebnych do kultu religijnego. Prawo do posiadania literatury religijnej obejmuje nie tylko prawo do posiadania tzw. „świętych ksiąg”, czyli najważniejszych dzieł religijnych, ale także prawo do posiadania specjalnej literatury umożliwiającej samokształcenie. W ustawie nie nastąpiło sprecyzowanie pojęcia przedmiotów potrzebnych do kultu religijnego. W praktyce funkcjonowania jednostek systemu penitencjarnego Rosji zalicza się do nich: ikony, obrazy, symbole religijne, krzyżyki, medaliki itp. Warto zauważyć, że dostępność do przedmiotów potrzebnych do kultu religijnego jest ograniczana w przypadku, gdy są one wykonane tak, że mogą zagrażać życiu lub zdrowiu. Dotyczy to zatem np. przedmiotów o ostrych krawędziach lub wykonanych z materiałów niebezpiecznych lub o dużej wadze. Ustawodawca zastrzega przy tym, że prawo to jest realizowane przy poszanowaniu wolności sumienia i wyznania innych osób oskarżonych i podejrzanych o popełnienie przestępstwa. Praktycznym skutkiem przyjęcia takiego rozwiązania jest także zakaz posiadania literatury religijnej i przedmiotów potrzebnych do kultu religijnego przez wyznawców religii lub odłamów religijnych o charakterze ekstremistycznym.

Ustawa federalna z dnia 15 lipca 1995 r. o zatrzymaniu podejrzanych i oskarżonych o popełnienie przestępstwa dopuszcza na podstawie art. 18 możliwość spotkań osób podejrzanych i oskarżonych z osobami duchownymi na podstawie pisemnej zgody organu prowadzącego postępowanie karne. Podejrzanemu i oskarżonemu ustawodawca zapewnia możliwość 
nie więcej niż dwóch wizyt w miesiącu. Mogą one trwać nie dłużej niż po trzy godziny każda. Bez odpowiedzi pozostaje pytanie, dlaczego ustawodawca wybrał właśnie takie ujęcie problemu i czym kierował się ustalając maksymalny limit 3 godzin. Wprowadzenie ograniczeń godzinowych dla spotkań z kapelanami wydaje się godzić w istotę wolności sumienia i wyznania.

Spotkania z osobami duchownymi odbywają się pod kontrolą pracowników miejsca pozbawienia wolności. W przypadku próby przekazania podejrzanym lub oskarżonym zabronionych przedmiotów, substancji i środków spożywczych lub informacji, które mogłyby utrudnić ustalenie prawdy w sprawie karnej lub przyczynić się do popełnienia przestępstwa wizyta zostaje natychmiast przerwana przed czasem jej zakończenia.

Podsumowując, katalog szczegółowych uprawnień wynikających z konstytucyjnej wolności sumienia i wyznania osób przebywających w rosyjskim systemie penitencjarnym jest regulowany w wielu aktach normatywnych. Przepisy prawne są jednak ogólnikowe i jak wydaje się mało precyzyjne. Co więcej, pojawiają się wątpliwości co do ich zgodności $\mathrm{z}$ regulacją konstytucyjną. Zapewne w niedługiej perspektywie czasowej ustawodawca rosyjski będzie musiał dokonać stosownych korekt w tym zakresie. Warto w tym obszarze zarekomendować ustawodawcy rosyjskiemu rozwiązania stosowane na przykład w polskim systemie prawnym ${ }^{29}$.

INNE ŹRÓDŁA PRAWA REGULUJĄCE DUSZPASTERSTWO W SYSTEMIE PENITENCJARNYM FEDERACJI ROSYJSKIEJ

Cechą charakterystyczną rosyjskiej regulacji pozycji prawnej duszpasterstwa specjalnego jest występowanie umów o współpracy zawieranych między związkami wyznaniowymi i właściwymi organami państwa, w których następuje konkretyzacja zapisów ustawowych. Nie inaczej jest z regulacją duszpasterstwa więziennego w systemie penitencjarnym Federacji Rosyjskiej. Podstawę prawną do zawierania umów stanowi art. 14 ust. 4 pkt 1 Kodeksu karnego wykonawczego Federacji Rosyjskiej z 8 stycznia 1997 r. Stanowi on, że - w celu zapewnienia wolności sumie-

29 Nikołajew 2012. 
nia i wyznania skazanych w zakładach karnych - federalny system penitencjarny zawiera umowy o współpracy z centralnie zarejestrowanymi organizacjami religijnymi. Także organy terytorialne systemu penitencjarnego są uprawnione do zawierania (w porozumieniu $\mathrm{z}$ federalnym systemem penitencjarnym) takich umów z wymienionymi organizacjami religijnymi.

W celu konkretyzacji zapisów ustawowych zawarto kilka porozumień ramowych o współpracy między FSWWR a zarejestrowanymi scentralizowanymi organizacjami religijnymi. Dodatkowo zawierane są porozumienia o wzajemnej współpracy między zarządami regionalnymi FSWWR i terenowymi strukturami organizacyjnymi związków wyznaniowych. Do najważniejszych porozumień zaliczyć należy: porozumienie ramowe o współpracy Rosyjskiego Kościoła Prawosławnego i FSWWR z dnia 22 lutego 2011 r. $^{30}$, porozumienie ramowe o współpracy Rady Muftich Rosji z FSWWR z 12 maja 2010 r. ${ }^{31}$ oraz porozumienie ramowe o współpracy Tradycyjnej Buddyjskiej Sanghi Rosyjskiej z FSWWR podpisane 30 grudnia $2010 \mathrm{r}^{32}$ Zawarte porozumienia ramowe mają charakter wzorcowy dla innych związków wyznaniowych. Brak jest ogólnie dostępnych informacji o liczbie zawartych umów ramowych między związkami wyznaniowymi a FSWWR.

Przykładem porozumień o wzajemnej współpracy zawieranych między zarządami regionalnymi FSWWR i terenowymi strukturami organizacyjnymi związków wyznaniowych jest umowa o współpracy między FSWWR w regionie Samary a Centralną Organizacją Religijną Ortodoksyjnego Judaizmu, Federacją Rosyjskich Wspólnot Żydowskich ${ }^{33}$.

Zarówno filozofia porozumienia ramowego, jak i porozumienia z terenowymi strukturami organizacyjnymi związków wyznaniowych sprowadza się do tego, że związek wyznaniowy ma prawo do udzielania posługi religijnej tylko w przypadku indywidualnego wniosku zainteresowanej

30 Tekst porozumienia na stronnie http://www.patriarchia.ru/db/text/1492496.html [dostęp: 09.10.2019].

31 http://www.fsin.su/news/index.php?ELEMENT_ID=4478\&sphrase_id=859530 [dostęp: 09.10.2019].

32 http://www.fsin.su/news/index.php?ELEMENT_ID=11098\&sphrase_id=859530 [dostęp: 09.10.2019].

33 https://www.samddn.ru/novosti/novosti/podpisano-soglashenie-mezhdu-federatsiey-evreyskikh-obshchin-rossii-i-ufsin-po-samarskoy-oblasti/ [dostęp: 09.10.2019]. 
osoby skazanej, podejrzanej lub oskarżonej i jednocześnie będącej wyznawcą konkretnej religii. Porozumienia zakazują prowadzenia szeroko rozumianej agitacji religijnej i każdej innej działalności, której celem jest prozelityzm. Związek wyznaniowy, który zawarł takie porozumienie, obejmuje opieką duszpasterską nie tylko osoby skazane, podejrzane i oskarżone, ale również personel FSWWR danego wyznania wraz z członkami ich rodzin.

Na podstawie porozumienia ramowego władze związku wyznaniowego powołują kapelanów więziennych do wszystkich jednostek organizacyjnych systemu penitencjarnego. Natomiast na podstawie porozumienia z terenowymi strukturami organizacyjnymi związków wyznaniowych, władze związku wyznaniowego powołują kapelanów więziennych tylko do konkretnej jednostki organizacyjnej wchodzącej w skład systemu penitencjarnego.

Kapelani więzienni przechodzą szkolenie przygotowawcze w specjalnych ośrodkach i są zobowiązani do współpracy z nie tylko z kierownictwem, ale i całym personelem jednostek systemu penitencjarnego.

\section{FEDERALNA SŁUŻBA WYKONYWANIA WYROKÓW ROSJI}

Federalna Służba Wykonywania Wyroków Rosji została powołana do życia w ramach szeroko zakrojonej reformy organów władzy wykonawczej przeprowadzonej w 2004 r. Podstawę prawną funkcjonowania FSWWR stanowią: Dekret Prezydenta Federacji Rosyjskiej z 9 marca 2004 r. (nr 314) „W sprawie systemu i struktury federalnych organów wykonawczych" 34 oraz Dekret Prezydenta Federacji Rosyjskiej z 13 października 2004 (nr 1314) „Zagadnienia Federalnej Służby Penitencjarnej”35.

Federalna Służba Wykonywania Wyroków Rosji jest federalnym organem władzy wykonawczej sprawującym kontrolę i nadzór nad wykonywa-

34 Ukaz Prezydenta RF ot 9 marta 2004 g. No 314 O sistiemie i strukture federalnych organow ispołnitielnoj własti. Tekst dekretu dostępny na stronie: http://www.consultant.ru/ document/cons_doc_LAW_46892/[dostęp: 11.10.2019].

35 Ukaz Prezydenta RF ot 13 oktiabria 2004 g. No 1314 Woprosy Fiedieralnoj Służby Ispołnienija Nakazanij. Tekst dekretu dostępny na stronie: http://www.consultant.ru/document/cons_doc_LAW_49893/[dostęp: 11.10.2019]. 
niem sankcji karnych wobec osób: skazanych, podejrzanych oraz oskarżonych o przestępstwa. Organ ten jest kontrolowany i nadzorowany przez Ministra Sprawiedliwości Federacji Rosyjskiej.

Do najważniejszych kompetencji FSWWR zaliczyć należy: wykonywanie zgodnie $\mathrm{z}$ ustawodawstwem rosyjskim kar oraz tymczasowego aresztowania $\mathrm{w}$ sposób zabezpieczający prawidłowy tok postępowania karnego, ochrona społeczeństwa przed sprawcami przestępstw osadzonymi w jednostkach systemu penitencjarnego, zapewnianie przestrzegania prawa i porządku w jednostkach systemu penitencjarnego, zapewnienie ochrony praw, wolności i uzasadnionych interesów osób skazanych oraz osób przebywających w areszcie, ochrona i konwojowanie skazanych i zatrzymanych, prowadzenie działalności resocjalizacyjnej, organizacja działań pomagających skazanym w adaptacji społecznej, zapewnienie bezpieczeństwa osób na terenie jednostek penitencjarnych oraz zapewnienie bezpieczeństwa obiektów i wyposażenia wchodzących w skład systemu penitencjarnego Rosji ${ }^{36}$.

Federalną Służbą Wykonywania Wyroków Rosji kieruje Dyrektor. Jest on powoływany i odwoływany przez Prezydenta Federacji Rosyjskiej. Dyrektor służby może mieć do siedmiu zastępców. Jeden z nich jest jego pierwszym zastępcą. Zastępców dyrektorów także powołuje i odwołuje Prezydent Federacji Rosyjskiej. W służbie funkcjonują stopnie na wzór wojskowy. Najwyższym stopniem jest generał służby wewnętrznej Federacji Rosyjskiej (generał czterogwiazdkowy).

Struktura FSWWR jest bardzo rozbudowana i złożona ${ }^{37}$. Składają się na nią: areszty śledcze, kolonie karne, kolonie edukacyjne dla osób niepełnoletnich, więzienia, centrala z 18 departamentami merytorycznymi, 8 zarządów generalnych, 8 zarządów regionalnych, jednostki „specnazu”38, 7 szkół wyższych, ośrodki szkoleniowe, instytuty badawcze, laboratoria,

36 Tamże, pkt. 3 Dekretu.

37 http://fsin.su/fsin/structure/ [dostęp: 03.11.2019].

38 Siły specjalne Federalnej Służby Wykonywania Kar Rosji. Jednostki mają charakter uderzeniowy. Ich celem jest zapobieganie przestępstwom, zatrzymywanie szczególnie niebezpiecznych przestępców, zapewnianie bezpieczeństwa podczas wydarzeń specjalnych, zwalnianie zakładników wziętych przez więźniów, a także ochrona wyższych urzędników departamentu oraz udział w operacjach antyterrorystycznych. Nie jest znana liczba jednostek specnazu ani ich liczebność. 
Centrum Higieny i Epidemiologii, szpitale, szpitale psychiatryczne, przychodnie, sanatoria, wydawnictwo oraz wiele innych. O wielkości systemu penitencjarnego Rosji świadczy m.in. liczba pełniący służbę funkcjonariuszy i zatrudnionych pracowników - w sumie jest to 295967 osób ${ }^{39}$.

\section{PRAKTYKA FUNKCJONOWANIA ZWIĄZKÓW WYZNANIOWYCH W SYSTEMIE PENITENCJARNYM FEDERACJI ROSYJSKIEJ}

Na podstawie oficjalnych danych FSWWR według stanu na dzień 1 października 2019 r. W systemie penitencjarnym funkcjonowały 1074 prawosławne cerkwie lub kaplice cerkiewne oraz sale modlitewne, 406 meczetów i sal modlitewnych dla osób wyznających islam, 24 świątynie buddyjskie oraz sale modlitewne dla osób praktykujących buddyzm w trzech tradycjach, 11 kościołów, kaplic i sal modlitewnych dla osób wyznających katolicyzm, 17 synagog i sal modlitewnych dla wyznawców judaizmu oraz 22 kaplice i sale modlitewne przeznaczone dla osób wyznających inne religie ${ }^{40}$. W sumie w jednostkach rosyjskiego systemu penitencjarnego funkcjonują 1554 obiekty (świątynie, kaplice, sale modlitewne) wykorzystywane do ceremonii i obrzędów religijnych.

Dane te świadczą o znaczącymi - wręcz skokowym - wzroście liczby świątyń, kaplic i sal modlitewnych w rosyjskim systemie penitencjarnym. Warto przypomnieć, że według oficjalnych danych z 2015 roku w rosyjskim systemie penitencjarnym było 547 cerkwi, 61 meczetów, 10 świątyń buddyjskich i 3 kościoły ${ }^{41}$.

Ze względu na liczbę osadzonych wiernych i zakres prowadzonej działalności duszpasterskiej największą rolę w systemie penitencjarnym Rosji odgrywa Rosyjski Kościół Prawosławny. Działalnością Kościoła w tym obszarze kieruje i ją koordynuje Wydział Synodalny ds. Służby

39 Dane dostępne są na stronie Federalnej Służby Wykonywania Kar Rosji, http://fsin.su/structure/inspector/iao/statistika/Kratkaya\%20har-ka\%20UIS/ [dostęp: 12.10.2019].

40 Dane dostępne są na stronie Federalnej Służby Wykonywania Kar Rosji, http://fsin.su/structure/inspector/iao/statistika/Kratkaya\%20har-ka\%20UIS/ [dostęp: 11.10.2019].

41 Matwiejuk 2016, 258. 
Więziennej ${ }^{42}$. Odpowiada on za współpracę z jednostkami organizacyjnymi rosyjskiego systemu penitencjarnego oraz politykę resocjalizacyjną i oświatowo-wychowawczą prowadzoną w stosunku do osób pozbawionych wolności wyznania prawosławnego. Misję duszpasterską w systemie penitencjarnym Rosji sprawuje około 1500 duchownych. W 8 głównych zarządach regionalnych FSWWR powołani są pomocnicy kierownika głównego regionalnego zarządu ds. pracy z osobami wierzącymi, wskazani przez właściwego terytorialnie ordynariusza diecezjalnego. Pomocnik jest pracownikiem etatowym i jest wynagradzany z budżetu FSWWR. Jego zadaniem jest nadzór nad wszystkimi kapelanami prawosławnymi pełniącymi posługę w regionalnych jednostkach penitencjarnych. Kapelani w regionalnych jednostkach penitencjarnych nie otrzymują wynagrodzenia i są wynagradzani przez właściwego biskupa diecezjalnego. Zgłaszane są postulaty zmiany takiego stanu rzeczy i przyjęcia duszpasterzy więziennych do służby etatowej w FSWWR.

Brak jest ogólnodostępnych danych o liczbie kapelanów więziennych $\mathrm{z}$ innych związków wyznaniowych niosących duchowną posługę w rosyjskim systemie penitencjarnym.

Reaktywowanie i dynamiczny rozwój duszpasterstwa więziennego największych konfesji wyznaniowych w Rosji przynosi pozytywne skutki świadczące o normalizacji stosunków wyznaniowych w państwie i współpracy państwa ze związkami wyznaniowymi. Pojawienie się kapelanów więziennych zapewne wpłynie w niedalekiej perspektywie na zmniejszenie się przestępczości i patologii w jednostkach organizacyjnych systemu penitencjarnego oraz podniesie standardy bytowe i sanitarne ${ }^{43}$ występujące w rosyjskim systemie penitencjarnym.

\section{PODSUMOWANIE}

Duszpasterstwo więzienne w systemie penitencjarnym Federacji Rosyjskiej jest instytucją o niedługim rodowodzie. Wielkość rosyjskiego systemu penitencjarnego oraz negatywne doświadczenia z okresu Związku

42 http://www.patriarchia.ru/db/text/141716.html [dostęp: 09.10.2019].

43 Pierzchała 2017, 69-70. 
Radzieckiego - gdzie duszpasterstwo więzienne nie istniało, a osadzeni nie mieli zagwarantowanej wolności sumienia i wyznania nawet w minimalnym stopniu - utrudniały po upadku komunizmu szybkie upowszechnienie opieki duszpasterskiej w jednostkach penitencjarnych. W ostatnich latach, w szczególności w okresie sprawowania urzędu Prezydenta Federacji Rosyjskiej przez Władimira Władimirowicza Putina, zaobserwować można odrodzenie instytucji kapelaństwa więziennego i dynamiczny rozwój wielokonfesyjnej opieki duszpasterskiej w instytucjach penitencjarnych.

Funkcjonowanie duszpasterstwa więziennego w Rosji opiera się o zróżnicowane podstawy prawne. Regulację normatywną tworzą normy konstytucyjne, ustawowe oraz inne, w tym umowy zawierane ze związkami wyznaniowymi, co jest cechą charakterystyczną tego modelu. Regulacja normatywna jest jednak stosunkowo lakoniczna i pozostawia spory obszar do interpretacji. Pojawiają się także wątpliwości co do konstytucyjności niektórych przepisów ustawowych.

Uzasadniony wydaje się więc wniosek o potrzebie korekty i doprecyzowania normatywnych rozwiązań związanych z funkcjonowaniem rosyjskiego systemu duszpasterstwa więziennego w celu jeszcze bardziej skutecznego zagwarantowania wolności sumienia i wyznania osobom pozbawionym wolności. Warto $\mathrm{w}$ tej materii skorzystać ze sprawdzonych rozwiązań międzynarodowych, w tym także polskich, określających pozycję duszpasterstwa więziennego w systemie penitencjarnym, który - co należy podkreślić - generalnie można uznać za modelowy na obszarze byłych państw socjalistycznych.

\section{BIBLIOGRAFIA}

Bagłaj, Marat Wiktorowicz. 2002. Konstitucjonnoje Prawo Rossijskoj Federacji. Moskwa: Wydawnictwo Norma.

Bajdakov, Gienadij Pietrowicz. 1995. „Prawowyje osnowy regulirovanija diejatielnosti religioznych organizacji w ispravnitielnych uczrezdenijach Rossii”. W: Sovierszestvovanije zakonodatielstva i praktyki uczrezdenij, ispolniajuszczych nakazania na osnovie Konstitucji Rossijskoj Federacji. Tezisy dokladov i soobszczenij, red. G.A. Tumanov, 91-96. Moskwa: Wydawnictwo GA. 
Barchatowa, Jelena Juriewna. 2018. Kommentarij k Konstytucji Rossijskoj Federacji, Moskwa: Wydawnictwo Prospekt.

Conquist, Robert. 1997. Wielki Terror. Warszawa: Wydawnictwo Michał Urbański.

Dietkow, Michaił Grigoriewicz. 1999. Tiurmy, lagieria i kolonii Rossii. Moskwa: Wydawnictwo Werdikt-IM.

Iwanow, Wasilij Iwanowicz. 2002, Kommentarij k Konstitucji Rossijskoj Federacji. Moskwa: Wydawnictwo Norma.

Krukowski, Józef. 2008. Polskie prawo wyznaniowe. Warszawa: Wydawnictwo LexisNexis.

Malinin, Wasilij Borysowicz. 2010. Ugołowno-ispotnitielnoje prawo: uczebnik dlia juridiczeskich wuzow i fakultietow. Moskwa: Wydawnictwo Wolters Kluwer Russia.

Matwiejuk, Jarosław. 2016. Konstytucyjno-ustawowa pozycja zwiąków wyznaniowych w Federacji Rosyjskiej. Białystok: Wydawnictwo Temida 2.

Michalski, Damian. 2018. „Kolonie karne na terenach Federacji Rosyjskiej - rys historyczny". W: Systemy penitencjarne świata, red. Damian Michalski, Kamil Dominik Ryś, 9-19. Olsztyn: Uniwersytet Warmińsko-Mazurski; http:// www.uwm.edu.pl/mpp/wp-content/uploads/9788394929251.pdf [dostęp: 27.08.2019].

Nikołajew, Jerzy. 2012. Wolność sumienia i religii skazanych i tymczasowo aresztowanych, Lublin: Wydawnictwo KUL.

Pierzchała, Kazimierz. 2017. „Rosyjski system penitencjarny w ujęciu wybranych polskich i rosyjskich opracowań". Nowa Polityka Wschodnia 4(15): 60-76.

Smirnow, Andriej Michajłowicz. 2013. „Teoretiko-prawowyje osnowy obespieczenija praw osużdiennych na swobodu sowiesti i swobodu wieroispowiedowanija w Rossii”. Jurist 4: 2-5.

Vshivkova, Alena Anatolyevna. 2015. „Obespieczenije prawa swobody sowiesti i swobody wieroispowiedowanija osużdionnych, nachodiaszczychsia w miestach liszeniaj swobody w Rossijskoj Fiedieracji”. Mołodoj Uczionyj 19: 475-478.

Zemskov, Victor. 1991. „GULAG (aspekt historyczny i socjologiczny)”. Sociological Research 6-7: 10-27.

Żezłow, Nikołaj Władimirowicz. 2016. „Prawowoje regulirowanije swobody wieroispowiedowanija w ugołowno-ispołnitielnoj sistiemie Rossii”. Rossijskoje prawo. Obrazowanie. Praktika. Nauka 6: 60-63. 


\section{PASTORAL CARE IN THE PENITENTIARY SYSTEM OF THE RUSSIAN FEDERATION}

\section{Summary}

The main purpose of this article is to present the constitutional, statutory and substatutory conditions of the functioning of prison chaplaincy in the Russian Federation. The study also discusses the practice of the functioning of prison chaplaincy currently being reborn in Russia, identifies the main problems and describes the growing role of religious organizations in this respect. At the same time, a general characterization of the Russian penitentiary system is made against this background, indicating its key elements, including the central management body - the Federal Service for the Enforcement of Judgments of Russia. Additionally, the article points out the imperfections of the applicable legal regulations and the practice of state organs related to the functioning of prison chaplaincy in the Russian Federation. The study concludes by presenting the prospects for further evolution of the legal position of prison chaplaincy in Russia, underlining that it is necessary to reform the Russian system of prison chaplaincy in order to effectively guarantee freedom of conscience and religion to persons deprived of liberty.

Key words: Russian Federation; freedom of conscience and religion; Federal Service for the Enforcement of Judgments of Russia; penitentiary system; prison chaplaincy; chaplain 
